\title{
IMPROVING THE METHOD OF EVALUATING THE EFFECTIVENESS OF THE COTTON GINS DEVELOPMENT STRATEGY
}

\author{
Tokhir Kuliev \\ Doctor of Technical Sciences, General Director of the JSC "Cotton Industry Research \\ Center”, Tashkent, Uzbekistan, \\ Sherzod Mardonov \\ Independent researcher of the JSC “Cotton Industry Research Center”, Tashkent, Uzbekistan
}

\begin{abstract}
The issue of improving the method of assessing the effectiveness of future development marketing strategies of cotton ginneries has been studied in the article. The country is taking comprehensive measures to develop the cotton industry, modernize and re-equip ginneries, increase the profitability of production and processing of raw cotton, as well as the competitiveness of its products. At the same time, the real state of affairs in this area indicates the rapid renewal and modernization of production processes, the introduction of advanced technologies and modern methods of corporate governance, the existence of systemic problems and shortcomings that hinder the rapid development of the industry.
\end{abstract}

Key words: Raw Cotton, Cotton Ginning, Development strategy, Method, Evaluation, Effectiveness

Cite this Article: Tokhir Kuliev and Sherzod Mardonov, Improving the Method of Evaluating the Effectiveness of the Cotton Gins Development Strategy, International Journal of Management, 11(12), 2020, pp 1279-1285.

http://iaeme.com/Home/issue/IJM?Volume=11\&Issue=12

\section{INTRODUCTION}

The transition to a market economy and constant changes in the conditions of domestic and foreign trade require transition to market relations - a comprehensive study of the conditions and their specifics. Currently, serious attention is being paid to the development of the cotton sector, which is one of the most important sectors in strengthening the country's export potential. In the meantime, the issue of launching the production of finished products by implementing the policy of structural changes in the economy remains relevant. Therefore, as a result of deep processing of cotton fiber, our government pays serious attention to the finished product output. So, "the Strategy for further development of the Republic of 
Uzbekistan for 2017-2021 sets important tasks, including" ... deepening structural reforms, increasing their competitiveness through modernization and diversification of the leading sectors of the national economy, ... [1]. Therefore, one of the important tasks is to implement structural changes in the cotton sector and related processing industries aimed at the production of final products. Currently, our government pays serious attention to the production of finished products as a result of deep processing of cotton fiber. At the same time, due to the shortage of raw materials in the cotton ginning industry, there are cases of inefficient use of existing production capacities and resources. While competition in the global market increases the uncertainty of the future development process, one of the important issues is the successful implementation of strategic alternative development options that meet the goals and objectives of the enterprise and can influence internal and external factors.

Therefore, based on the results of an in-depth study of the principles and rules of marketing, the organization of effective marketing services in gins, evaluating the effectiveness of the chosen marketing strategy is an urgent problem.

\section{LITERATURE REVIEW}

At this stage, there are several approaches for evaluating the effectiveness of the strategy. The effectiveness of a strategy cannot be based on the effectiveness of projects and requires special functions. For instance, Yu.N. Lapygin identifies the following key features of a potentially effective strategy [2]:

- The essential correctness of the chosen strategy;

- The uniqueness of the strategy (to be successful, the company's strategy must include its strengths and opportunities that create competitive opportunity);

- Future uncertainty as a strategic opportunity (changes in the external environment create threats and new additional opportunities that need to be explored and used to reach future success);

- Flexibility (strategic changes in the company itself must correspond to external changes in order to realize the opportunities provided by the external environment).

In my opinion, this approach is effective, on one hand, but at the same time it is incomplete and difficult to assess, since it is very difficult to objectively assess these features.

However, according to G. Mintsberg, "the latest information about the success of organizations in modern conditions does not fit into the framework of any school of strategic management" [3].

There is another approach. For example, T.A. Zubov considers that the effectiveness of the strategy can be evaluated in two ways [4]:

- Evaluate the developed strategic alternatives to determine their suitability, relevance, acceptability and sustainability for the company;

- Comparing the results of the strategy implementation with the planned ones.

Moreover, a number of problems arise when applying the target model:

- companies can have many goals;

- the company's goals are quite specific;

- using a time perspective: a successful result in the short term may fail in the long term;

- The problem of differences in relation to events inside and outside the organization. 
Due to the problem of measuring the target effectiveness of a strategy depends on the accuracy of the firm's performance targets [5].

- The following basic requirements must be met when setting goals:

- goals should directly reflect the business logic and selected strategic guidelines;

- goals should be clear and presented as quantitative indicators that can be tracked and controlled;

- Quantitative indicators should be established relative to the initial situation in the company.

It is worth noting the system of balanced indicators of R. S. Kaplap and D. Norton (BIS) [6].

Another approach for evaluating the effectiveness of strategic management is the theory of stakeholders. E. Freeman considers a company as a set of stakeholders whose activities should take into account its external and internal environment, its interests and requirements. There is also an approach that assumes that effective business strategy should create added value for consumers in the first place. The added value must be properly accepted by customers. Perhaps the problem lies in the communicative difficulties of reflecting the value, or in the complete absence of such communication.

The problem of perceived value is particularly acute when the customer cannot adequately assess the added value of a product or service. To understand the difference between competitive commercial offers, the buyer needs to spend a lot of time and effort. Therefore, the company's task is to manage these types of signals or tokens with added value.

A.Sh. Bekmurodov developed a methodology based on a targeted approach to evaluating the effectiveness of marketing, which was defined as the ratio of the effectiveness of marketing costs to the share of profit growth in the share of marketing costs.

M.R. Boltaboev when calculating the effectiveness of the marketing mix complex in the export of cotton fiber, the ratio of the amount of profit received through the implementation of marketing activities to the cost of implementing these measures is used.

These efforts have involved many developers in conducting well-designed book work to increase marketing effectiveness and increase interest in all efforts and reading.

The practical application of such marketing effectiveness detection methodologies will come up with many challenges in carrying out the calculations by dividing the profits and costs into separate pieces.

\section{RESEARCH METHODOLOGY}

Foreign and local researchers on the research topic relied on the results of the research, and methods such as statistics, selective observation, comparison, expert evaluation were used.

\section{RESULTS AND DISCUSSION}

On our side, it is proposed to use an integrated assessment system, which includes a comprehensive assessment of the effectiveness of the development strategy of cotton ginneries $[7,8]$.

Unlike existing methods, the effectiveness of the marketing strategy for the development of ginneries is considered as a combination of three components: the quality of the strategy $K_{c}$; strategic effectiveness $-K_{c}$ and goal achievement indicator (effectiveness) - $K_{c}(1)$ :

$$
E_{c}=f\left(K_{c}, C_{c}, M_{d}\right)
$$


When it comes to the quality of the strategy, it is understood that the relative indicators of the strategy correspond to the development trends of the external environment, its dynamics, flexibility, control, compliance with the capabilities of the company, objectivity, consistency of the company's strategy with the regional development strategy, etc.

We suggest using the following parameters to assess the quality of the strategy:

- consistency of enterprise corporate strategy with external environment conditions and parameters;

- compliance with the development strategy of the region (or compliance with the interests of the region and the country);

- compliance of the strategy with the objectives of the enterprise;

- consistent with the internal potential of the enterprise's corporate strategy;

- internal balance of parameters of the enterprise's corporate strategy;

- ability to implement the strategy on account of available technological, labor and financial resources;

- eligibility for stakeholders (to respond as much as possible to the interests of the stakeholders);

- to create superiority in competition;

- Optimal level of risks associated with the implementation of the enterprise's corporate strategy.

The most effective quality strategy was identified at the selection stage of several strategic alternatives implemented in the previous paragraph of the study, and a proactive strategy option was selected as the most effective of the three strategic options for the cotton ginnery under study.

Strategic efficiency is a qualitative change in the enterprise, which is predicted in the long term based on the results of the implementation of this strategy. It is determined on the basis of a specific situation and a particular enterprise.

An assessment of the proactive strategic alternative showed that its implementation increases profitability, which allows the company to maintain a level of profitability, thereby increasing the level of satisfaction of the needs of the domestic market.

The final stage of evaluation will be to what extent the company's objectives have been achieved in the implementation of this strategy. The level of achievement of the goal is defined as the level of compliance of the result achieved in the implementation of this strategy with the set goals, i.e.:

$$
E_{c}=\frac{E_{f}}{E_{r}}
$$

Where, $E_{f}-$ the result obtained in reality; $E_{r}$ - planned result.

The integrated assessment of the effectiveness of the development and implementation of the marketing strategy of cotton ginneries is determined by using the following formulas:

$$
K_{c}=\sqrt{K_{K_{c}} \cdot K_{C_{C}} \cdot K_{M_{d}}}
$$

Where, $K_{K_{c}}-$ coefficient of strategy quality; $K_{C_{c}}-$ strategy effect coefficient; $K_{M_{d}}-$ coefficient of achievement of the strategy goal. 
The integral indicator of the effectiveness of the Marketing strategy receives a value from 0 to 1 . The scale is presented in Table 1 to evaluate the effectiveness of marketing strategy on the basis of Integrated Performance.

Table 1. The scale of the evaluation of the effectiveness of the marketing strategy of a cotton ginnery

\begin{tabular}{|l|l|}
\hline \multicolumn{1}{|c|}{ Integral Indicator Result } & \multicolumn{1}{c|}{ Evaluation Content } \\
\hline from 0 to 0.30 & Critical \\
from 0.31 to 50 & Unsatisfied \\
from 0.51 to 70 & Satisfactory \\
from 0.71 to 0.85 & Good \\
from 0.86 to 1 & Ideal (Excellent) \\
\hline
\end{tabular}

This evaluation is carried out in the process of implementation of the strategy after obtaining the result.

The strategic Efficiency $-S_{E}$ and the level of achievement of the target were assessed on the basis of the application of the balanced scorecard (BSC) in the implementation of the selected proactive strategy in cotton ginneries. Due to this, the most important strategic goal of the cotton ginnery in the near future is to increase the production and sales of cotton raw materials by increasing the base, increase the level of profitability by reducing costs and ensure the level of growth of the value of the company. The developed pre-active marketing strategy of development was put into practice in 2019. The results are presented in table 2

Table 2. The main indicators of the growth strategy of the cotton ginnery in 2019

\begin{tabular}{|c|c|c|c|}
\hline $\begin{array}{c}\text { Base indicators } \\
\text { KPI }\end{array}$ & $\begin{array}{c}\text { Target value of } \\
\text { the indicator in } \\
2019\end{array}$ & $\begin{array}{l}\text { Value of the } \\
\text { indicator in } \\
\text { reality in } \\
2019 \text { KPI }\end{array}$ & $\begin{array}{l}\text { Performance } \\
\text { in } 2019, \%\end{array}$ \\
\hline \multicolumn{4}{|c|}{ The main strategic objective of the cotton ginnery } \\
\hline Sales volume growth rate & $6,8 \%$ & 7,4 & 108,82 \\
\hline Growth rate of enterprise value & $16 \%$ & 18,2 & 113,75 \\
\hline \multicolumn{4}{|c|}{ “Client" strategy } \\
\hline $\begin{array}{l}\text { Degree of change in the integrated } \\
\text { indicator of brand competitiveness }\end{array}$ & $15 \%$ & 18,1 & 120,66 \\
\hline $\begin{array}{l}\text { Rate of change in the number of } \\
\text { pushers }\end{array}$ & $6 \%$ & 6,4 & 106,66 \\
\hline \multicolumn{4}{|c|}{ Prospects for "Domestic business processes" } \\
\hline $\begin{array}{l}\text { The rate of change in production } \\
\text { costs of a unit of product }\end{array}$ & $0,6 \%$ & 0,84 & 140,0 \\
\hline Level of use of production capacity & Reach80 \% & 82,6 & 103,25 \\
\hline Fiber output indicator change rate & $1,6 \%$ & 2,2 & 137,50 \\
\hline \multicolumn{4}{|c|}{ "Finance" strategy } \\
\hline Rate of change in market share & $4,5 \%$ & 5,1 & 113,33 \\
\hline Rate of change in Net Profit & $5,2 \%$ & 6,4 & 123,07 \\
\hline $\begin{array}{l}\text { The degree of change in product } \\
\text { profitability }\end{array}$ & $7,8 \%$ & 8,64 & 110,77 \\
\hline $\begin{array}{l}\text { Change in the level of provision of } \\
\text { own funds }\end{array}$ & $35 \%$ & 36,2 & 103,43 \\
\hline
\end{tabular}




\begin{tabular}{|c|c|c|c|}
\hline \multicolumn{4}{|c|}{ "Teaching and developing" strategy } \\
\hline $\begin{array}{l}\text { Change in the proportion of staff } \\
\text { who have improved their skills }\end{array}$ & $24 \%$ & 28,0 & 116,66 \\
\hline $\begin{array}{l}\text { Change in employee satisfaction } \\
\text { level }\end{array}$ & Reach $100 \%$ & 96,0 & 96,0 \\
\hline $\begin{array}{l}\text { Change in the amount of cotton raw } \\
\text { materials to be prepared }\end{array}$ & Reach $80 \%$ & 82,6 & 103,25 \\
\hline $\begin{array}{l}\text { The rate of change in labor } \\
\text { productivity }\end{array}$ & $18 \%$ & 19,6 & 108,89 \\
\hline
\end{tabular}

Source: Author's calculation based on the data of the ginnery.

The data of table 2 indicate that effective measures have been developed in the implementation of the systemic-integrated concept of management of the implementation of growth marketing strategy in 2019 on the basis of the plans established in 2018 in this cotton ginnery, as well as the implementation of all KPI indicators as a result of ensuring their implementation within.

In particular, the main strategic goal of the company is to fill the deficit of raw cotton by $103.25 \%$, which is one of the main indicators of its processing - $0.6 \%$ more than the established level of fiber production - 7.4\% sales growth. It allowed increasing the growth rate of the enterprise value to $18.2 \%[8,9]$.

In the process of the study, it was determined that the quality of the strategy was equal to $K_{K_{c}}=0.92$ as a result of the re-evaluation given by experts.

Strategy two indicators characterizing the main strategic objective of the cotton ginnery in the balanced indicators system (BIS) as a basis for calculating the effective coefficient $K_{c_{c}}$ were obtained: sales volume growth rate (executed at $108.82 \%$ compared to the plan) and the growth rate of the enterprise value (executed at $113.75 \%$ compared to the plan). They are obtained as $K_{c_{c}}=1$, since the value provides for the achievement of the intended goal [10].

The strategy was taken as the basis for calculating the coefficient of achievement of the goal - $K_{M_{d}}$, indicators that characterize the prospects in the balanced system of indicators (BSC). The results show that only all indicators, except for the indicator "change in the level of satisfaction of employees" (performed to 96.0\%), characterize the achievement of the intended result. Therefore, $K_{M_{d}}=0.96$. Thus, the effectiveness of the implementation of the selected proactive marketing strategy of the cotton cleaning enterprise will be equal to:

$$
K_{c}=\sqrt{K_{K_{c}} \cdot K_{C_{C}} \cdot K_{M_{d}}}=\sqrt{0.92 \cdot 1.0 \cdot 0.96}=0.94
$$

Hence, the integrated indicator of marketing effectiveness in this cotton ginnery is equal to 0.94 , which is considered "excellent" according to the evaluation scale presented in Table 1. This is evidenced by the correctness of the selected marketing strategy for the growth of the cotton ginnery. This cotton ginnery has the potential to further increase sales as a result of the implementation of future diversification policies.

\section{CONCLUSIONS}

Based on the results of the research carried out, in order to improve the effectiveness of marketing strategies in cotton ginneries, attention should be paid to the following:

- it is necessary to formulate the structural structure of management in a cotton ginnery in a way that is adaptable to market changes;

- increasing the status of marketing service in the management structure of the cotton ginnery; 
- the organization of continuous market conjuncture study, the effective use of modern methods and means of conducting marketing research in this process;

- to carry out the evaluation of the effectiveness of marketing strategies, to develop a balanced system of indicators in the evaluation;

- choosing a marketing strategy option that will ensure the effectiveness of this service in the long term in the organization of marketing activities;

- organization of management of marketing results in cotton ginneries on the basis of modern methods and methods of management.

\section{REFERENCES}

[1] Decree of the President of the Republic of Uzbekistan dated February 7, 2017 no. PF-4947 "On the strategy of actions in five priority areas of development of the Republic of Uzbekistan for 2017-2021",

[2] LapyginYu.N. Theory of organization: textbook. - M., 2007. p. 311.

[3] Mintzberg,G.. Strategic Safari: a tour through the wilds of management strategies, Peter publishing house, 2000. p. 336.

[4] Zub, A.T. Strategic management: Theory and practice: textbook for universities, 2002. p.415.

[5] Bekmurodov A.Sh., Yang Son Be. Strategy for the development of the textile industry in Uzbekistan: a Cluster approach. Monograph. - T.: TSEU, 2006. p.112.

[6] Boltaboev M.R. Marketing strategy in the textile industry. Monographs. - T.: Science, 2004. p.223.

[7] O. I. Rajabov, A. S. Abrorov, N. I. Mirzaqulova, G. B. Zaripov, Kh. S. Ziyodullaev, An experimental study of the location of the grid bars cells installed under spiked cylinders in a cotton cleaner from small waste. IOP Conference Series: Materials Science and Engineering, 2020, 734(1) 012073.

[8] O.I. Rajabov, F.A.Fazliddin, M. H. Gapparova and J. Shakhrillo, The influence of the location of the cells on the allocation of weed impurities for cleaning raw cotton from fine waste. IOP Conference Series: Materials Science and Engineering, 2020, 734(1) 012073.

[9] Juraev Anvar and Rajabov Ozod, Analysis of the interaction of Fibrous Material with a Multifaceted Grid of the cleaner. International Journal of Recent Technology and Engineering, 8(1), 2019, pp. 2661-2666.

[10] Ozod Rajabov, Ziyodullo Shodiyev, Ikrom Inoyatov, Mastura Gapparova. Analysis of the Technological Process of Cleaning Raw Cotton from Small Trash. International Journal of Emerging Trends in Engineering Research, 8(9), 2020, pp. 6022-6029. 